\title{
Discussing Contemporary Racial Justice in Academic Spaces: Minimizing Epistemic Exploitation While Neutralizing White Fragility
}

\author{
Adele Norris
}

\section{Contents}

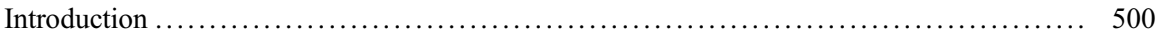

Emotional Discomfort and Discussions of Racism ........................... 501

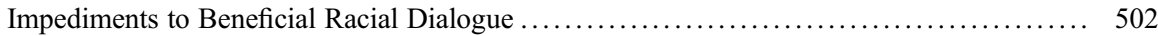

Situating my Social Location and Teaching Introduction to Sociology ............. 503

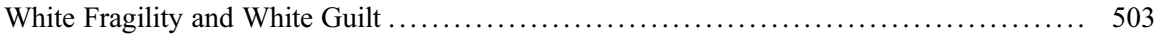

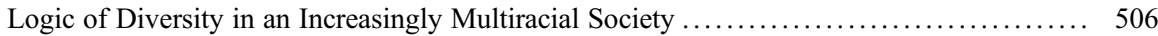

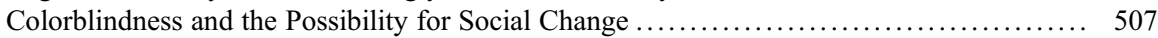

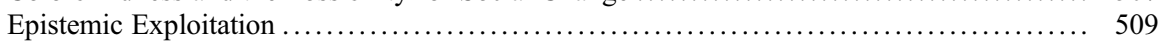

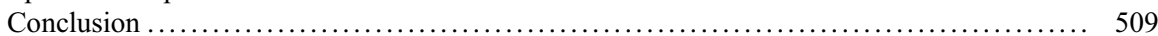

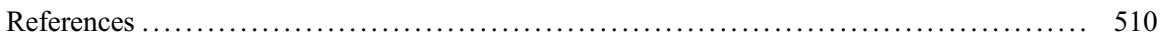

\begin{abstract}
In light of contemporary racial justice issues in the United States, the academic classroom can be a precarious environment to engage in intellectually humble dialogue on racial injustice. This chapter expands upon the concept of epistemic exploitation raised in Nora Berenstain's 2016 article, which explains the exploitative and emotionally taxing burden marginalized persons feel when compelled to educate privileged persons about their unearned privilege and the nature of marginalized person's oppression. I argue that epistemic exploitation is more likely to occur in academic classrooms if white guilt and fragility are not acknowledged and neutralized. My assertion is based on the premise that as racial justice conversations increasingly occur, the need to satisfy white fragility exceeds the need to engage in healthy discussions on racism and white supremacy. Race is, therefore, deemphasized and other social status markers (e.g., gender, class, age, sexuality orientation) are overly emphasized or are used as proxies
\end{abstract}

\footnotetext{
A. Norris $(\bowtie)$

School of Social Sciences, Sociology and Sociology Program, The University of Waikato, Hamilton, New Zealand

e-mail: adele.norris@waikato.ac.nz
} 
for race. In such cases, colonizing narratives of groups racialized as non-white are perpetuated via colorblind explanations about social problems.

\section{Keywords}

Epistemic exploitation $\cdot$ Racial justice $\cdot$ Diversity ideology $\cdot$ Colorblind ideology $\cdot$ White fragility/guilt

\section{Introduction}

In 1963, a racially contentious time in the United States, James Baldwin published the essay $A$ Talk to Teachers. During this time, racism, social inequalities, and stratification were severe and profound (Smith 2017). Given the 2017 neo-Nazi march across the University of Virginia campus and the ongoing gross police brutality against blacks - which spurred a national movement - we are, again, living in a contentious time. The message Baldwin (1963) delivered to educators in his essay is just as relevant today when he says that educators should not make peace with the conspiracies designed to destroy us but rather assume the obligation to teach students to examine society critically and truthfully. In Clint Smith's (2017) reflection on Baldwin's essay, Smith implores educators not to fall victim to wanting to create an apolitical space in the classroom. "The very decision to not discuss certain things in your classroom" he says, "is in and of itself, a political decision," especially when students' lives are impacted by political decisions every single day (Smith 2017, 3).

It is well documented that explicit and implicit social status markers (race/ethnicity, gender, social class, ability status, and sexual orientation) contribute to barriers that prevent people from engaging in open-minded, intellectually humble dialogue that stimulates a critical consciousness and engagement with the world (Berenstain 2016; Collins 2013; Lorde 1995; Nadan and Stark 2016; Smith 2017). My view, which serves as a pivotal aspect of this discussion, is that social status markers are more important in determining whether one accepts a particular position than is the content of the position itself. I posit that social cues, specifically related to race/ethnicity, trigger implicit biases and are more likely to drive academic discussions of injustices experienced by members of structurally disadvantaged racial groups than the need to unlearn colonizing narratives that are regurgitated within the classroom. For example, Katie Reilly's (2016) Time article, How Guns on Campus Could Change What Texas Teaches, draws attention to how gun laws influenced the removal of controversial content from university classrooms. In the wake of the campus-carry law, which allows Texans with concealed handguns license to carry guns on public university campuses, university professors were urged to consider changing their curricula to avoid controversial subjects (Reilly 2016).

Scholars have noted a new trend among racially conscious white individuals, on the one hand, ostensibly advocating for racial inclusion and challenge colorblind ideology, while, on the other hand, maintain white supremacy (Bell and Hartmann 
2007; Smith and Mayorga-Gallo 2017). With an increasingly multiracial society that seemingly celebrates efforts of diversity and inclusion, groups racialized as non-white often bear the burden to still prove their oppression (Berenstain 2016) while whiteness remains unquestioned (Smith and Mayorga-Gallo 2017). Berenstain (2016) refers to this process as epistemic exploitation. In an increasingly raceconscious society, expanding our understanding of epistemic exploitation is an important step if we are to advance academic discussions of racism and racial justice. This chapter argues, however, that as a part of deconstructing epistemic exploitation, careful and sustained attention must be used to identify the ways in which "white fragility" and "white guilt" are mobilized to establish a moral equivalence between all racial groups. Effectively a form of "White protectionism," as Charles Mills (1998) calls it, white people's claims of emotional injury and victimhood, fueled by the discourses of diversity and colorblind ideology, amplifies the epistemic exploitation of oppressed groups who are called upon to protect the white ego from reflective engagement with unearned privilege.

\section{Emotional Discomfort and Discussions of Racism}

I begin this discussion by first defining epistemic exploitation set forth by Nora Berenstain (2016). Epistemic exploitation occurs when individuals from racially/ethnically subjugated groups are called upon to educate individuals from racially privileged groups on their oppression and to prove that the systems of power that work to oppress them exist (Berenstain 2016). I argue that in order to avoid or limit epistemic exploitation, white guilt and fragility must be accounted for and neutralized. This will be challenging. My claim is grounded in the reality that contemporary racism arises in complex forms where diversity claims are in fact promoted by white individuals. However, many people hold subconscious or unarticulated racist beliefs, often without having considered that these beliefs are racist (such as, for example, the claim that the problem is solely social class based, rather than the possibility of racism). These forms call for innovative pedagogical strategies that examine the underlying beliefs that operate to reject or constrain one's understanding of institutional and structural racist practices. Essential to this complexity is the widespread belief that society has achieved racial equality. Those who are consistently told that racism is a problem of the past, will have some reason to cease to look for it as an explanation of behaviors and practices in the present. It is not surprising that students would grapple with examining features of modern-day racism, especially when many of them have grown up in a world where words such as diversity and multicultural are freely embraced and dominate mainstream discourses (Alexander 2012; Collin 2013; Davis 1996; Mohanty 2004; Norris 2017; Pitcher 2011; Smith and Mayorga-Gallo 2017; St. Clair and Kishimoto 2010). The problem arises when this discomfort is ignored and goes unexamined. Failing to examine the causes of our modern discomfort, both to talk and to hear about race and racism, stops us from understanding the extent to which it influences and impedes discussions of racism and racial justice. 
There is a growing scholarship on the emotional discomfort stimulated by discussing the nature of racism and racist stereotypes (Boler 1999; Burke 2017; Collins 2013; Ladner 1971; Nadan and Stark 2016; Zajicek 2002). Developing pedagogical strategies that equip students to reflect upon their personal biases is far from new and crosses disciplinary boundaries (Collins 2013; Cooper 2008; Boler 1999; Murphy-Erby et al. 2009; Nadan and Stark 2016). It is imperative students are equipped to engage in healthy discussions of racism, especially as social inequalities deepen and, through corporate media penetration, we are aware that the world is culturally diverse (Nadan and Stark 2016). Taking the stark reality that social inequality is both ubiquitous and is becoming worse as my point of departure, I now move to explicate its implications for the politics of embodied knowledge and emotional labor involved in respecting race-talk in the classroom.

The remainder of the chapter is organized into two parts. First, I situate this discussion in the philosophical context of epistemic exploitation. The extent that academic classrooms can effectively challenge racial hierarchies rather than replicate them rests upon the extent that such spaces can minimize epistemic exploitation while neutralizing white guilt and fragility. In doing so, the theoretical insights presented are supported by my personal experiences as a transnational educator who has taught Introduction to Sociology in two predominately white countries. Thus, this work poses theoretical arguments. Second and relatedly, I review three overlapping themes identified in the literature that often dominate formal classroom settings: (1) white guilt and white fragility, (2) diversity ideology, and (3) colorblind ideology. Each of these are core features inherent to the ubiquity of whiteness that dominate formal settings, which in turn influences the type of scholarly material utilized in classes, how it is delivered, and possibilities for how it is understood.

\section{Impediments to Beneficial Racial Dialogue}

Trayvon Martin, Michael Brown, Eric Garner, Sandra Bland, Walter Scott, Philando Castile, Alton Sterling, Terence Crutcher, and Jordan Edwards are only a few names embedded in the United States discourse on racism and police brutality. The untimely deaths of these African Americans coupled with the mass incarceration of black and brown people launched the widely known social justice movement, Black Lives Matter. Such dismal events are evidence of a growing twenty-first century racial justice problem with centuries old roots. Yet, contemporary understandings of the enormity of racial injustices lag considerably behind the urgency to achieve racial justice. The fight for racial equity has spurred a plethora of discussions; however, these discussions are too often tempered by the need to assuage white discomfort. That is, while communities, activists, and public figures alike are now willing to strongly criticize particular instances of violence against African Americans, fewer are as yet willing to analyze the structural and social features of institutions such as the police. Presumably this "hierarchy of credibility" is determined by the overdetermined ideological conception that police are "protectors" and neutral arbiters of conflict resolution. 


\section{Situating my Social Location and Teaching Introduction to Sociology}

As a heterosexual Black woman from rural Mississippi who has taught Introduction to Sociology and other sociology and women studies courses in two predominately white countries, speaking about racism comes fairly naturally. This ease comes in part because of my daily experiences, and I rely heavily on my experiences growing up in the Deep South during the 1980s. I inform my class of my earliest memories of having to learn about racism. Only a minority of students can relate to experiences of racism coupled with having to understand it at the age of five or six, especially during a time many students perceive as post-Civil Rights and therefore post-racial. But most of my comfort comes from having had to engage in hostile environments towards blacks and having hostile teachers most of my life. Such experiences bring with it an understanding and/or expectancy of white hostility and discomfort with discussions of race/racism. However, despite my comfort with delivering material on race/racism, most of my students do not share the same level of comfort hearing or learning about racism.

As with any topic, I am aware of students' engagement and receptiveness. While comfort levels for different topics vary across classrooms and geographic regions, I have recognized that with discussions of race/racism/white supremacy, there is a consistent hostility and discomfort that are more pronounced, which often manifest visibly (e.g., defensive body language, awkwardness) and verbally (e.g., types of questions posed, defensive comments and tone of voice). Albeit unknowingly, these responses work in tandem to gain control of the space and to direct the discussion to more palatable takes on racism or to complete dismissal. These types of responses are powerful and are also evidence that there is an acute lack of understanding of racial injustice and white supremacy despite the plethora of diversity and multicultural initiatives. I use this discomfort as evidence a problem exist, and then pose the question: How can we dismantle a system that we cannot discuss? While I do not gain everyone's attention, I do get enough students involved to counter classroom discomfort and get the class to a place for those who want to learn will gain some insights and confidence to challenge their peers.

\section{White Fragility and White Guilt}

Discomfort arises somewhere between acknowledgement of the problem and criticism of those enacting racism. In discussions of race in formal settings, like academic classrooms, emotional discomfort is often elevated to higher levels of importance than difficult and complicated substantive discussions of racism that are beneficial and productive. The concept of "safe space" is mobilized by whiteness to protect the biases and insecurities of white students, teaching assistants and even professors. Robin DiAngelo's (2011), ground breaking work on white fragility, regards theses dynamics as a function of whiteness. Consider the lengths public figures feel they must go to separate their criticism of particular police officers from any perceived criticism of the police as an institution, when speaking out 
against atrocities. This is the "bad apple" versus the "bad barrel" polemic, as if the two cannot exist simultaneously. The idea that police forces are institutionally racist cannot be broached without causing public discussion to veer away from the issues at hand, to a discussion about what criticisms can and should be uttered publicly. In this way "political correctness" is a slur projected at those seeking to legitimate alternative and oppositional narratives, whereas it is in reality discursive strategies that seek to constrain radical analysis that are politically correct.

Robin DiAngelo (2011) defines whiteness as including three fundamentals: (1) a location of structural advantage and race privilege; (2) a standpoint for which white people look at themselves, at others, and at society; and (3) a set of cultural practices that are usually tied to "othering" of non-white people. Goodman (2011) argues that the limited examination of whiteness is a societal cost connected to the predominant way history is told. Since history is told from the perspective of the dominant group that emphasizes and embellishes the accomplishments of this group, readers receive a partial and distorted view of the past (Baldwin 1963; Collins 2013; Goodman 2011). Poor exposure to an inclusive history, also a function of white supremacy (Baldwin 1963; Woodson 1933), limits and skews the views of different lifestyles, perspectives, and people (Goodman 2011). Consequently, a "whiteness conditioning" develops and impedes the critical interrogation of whiteness and privilege, especially by white students (Goodman 2011; Loewen 2007). Loewen (2007) identifies this issue as the primary reason white students, in particular, leave high school with weak to nonexisting foundations upon which to encounter knowledge about race and social inequalities. If the material is all/primarily told from a particular perspective, discussions will fail to make students leave the classroom thinking critically, which also speaks to the structural inequalities rooted in "diversity" initiatives. Meaning, the structural inequalities in society are maintained by the standard choices of educators regarding subject matter, such that even in classrooms with a diverse range of students from diverse backgrounds, the students do not develop critical approaches to knowledge.

Luft (2009) argues that it is important to first consider the logic of the system for which one plans to impart information or facilitate discussion. This process requires understanding varying levels of power in the classroom setting (Collins 2013). For example, DiAngelo (2011) argues that college courses designed to meet multicultural educational requirements rarely challenge the racial understanding of white students much less address white privilege and white supremacy. Instead the norm is to deliver information using racially coded language such as "urban," "inner city," or "disadvantaged" but rarely "white," "over-advantaged," or "privileged" (DiAngelo 2011, 55). Content designed to teach cultural competency that does not directly address racism inherently caters to the comfort of white students via the use of palatable language. Researchers note that in educational programs/courses that comprehensively tackle racism and the privileging of whites, a common response among white students is anger, withdrawal, emotional incapacitation, argumentation, and guilt (DiAngelo 2011; Smith and Mayorga-Gallo 2017; Spanierman et al. 2005). DiAngelo locates these reactions within the broader frame of white fragility. 
Advanced by Robin DiAngelo (2011), white fragility describes the condition when white people regard racial stress, even minimal, as intolerable. Widespread protection received by white people in social environments in North America insulates them to the point that their expectations for racial comfort are takenfor-granted as a right. Thus, white fragility evokes defensive reactions which include outward demonstrations of emotions (anger, fear, and guilt) and conduct (argumentation, silence, and leaving the stress-inducing situation), which all function to reinstate white racial equilibrium (DiAngelo 2011). In the broadest terms, white fragility, originates from the failure to understand and interrogate whiteness (DiAngelo 2011).

Critical race scholars focusing on whiteness pedagogy explain this discomfort as part of the complexity of white identity wherein guilt and fragility are often present but rarely confronted (DiAngelo 2011; Yeung et al. 2013). White guilt, as a domain of white identity (Lydacker et al. 2014) is a cognitive reaction of collective and individual awareness of unearned privileges and racism (Iyer et al. 2003; Swim and Miller 1999). Refusal to support ameliorative racial equity policies, cast in the context of white protectionism as unearned and unfair, amplifies white guilt, manifested as fragility, which in turn articulates itself through white projection onto the other. Conceptually, white guilt is a culturally and context-bound expression of guilt more generally: an emotion that combines self-deprecation and shame. Because white guilt is a consequence of systemic oppression and racism, its distinction lies in the process of reflecting on negative events and attributing blame about racial injustice to individuals and not a system of policies, institutions, and cultural norms (Lydacker et al. 2014).

Studies of white guilt are diverse, ranging from understanding the emotional influence on eating disorders, attitudes towards affirmative action, and pedagogical strategies (see, e.g., Iyer et al. 2003; Swim and Miller 1999; Goodman 2011). These studies highlight the value of understanding the benefits and limitations of group-based guilt (white guilt). Largely due to the unmarked but ever present nature of whiteness, white guilt receives little attention in racial and social justice discourses (DiAngelo 2011; Gans 2007; Goodman 2011; Todd and Abrams 2011; Zajicek 2002). Even when white guilt emerges in discussions of racism, some scholars question its effectiveness to bring about social change (Kirabo 2015; Younge 2015).

For example, in the debates surrounding the culture of racism in the United States after the 2015 Charleston church shooting, some have spoken of white guilt as an impediment to social change. Kirabo (2015) argues that an emotional response such as white guilt does not translate to an authentic understanding of contemporary racism and its structural formation. Thus, it is not an effective tool to combat social inequality and address prevalent racial injustices (Kirabo 2015; Younge 2015). The problem with white guilt, according to Kirabo (2015), is that it attempts to diminish the focus aimed at issues integral to marginalized groups and redirect attention to a wasteful plan of apologetics and ineffective assessments.

Since white guilt and fragility are unavoidable, it is important to discuss these modus operandi as integral components with the power to influence and obstruct 
valuable discussions on racial justice issues. Thus, a thoughtful understanding of white guilt and white fragility is required. Given the intensity and power of the emotional responses attached to discussions of racism, I argue that having a firm grasp of white fragility/guilt is as important as the content delivered. Individuals who do not learn to process these emotions in a healthy manner are less equipped to properly engage in and process discussions of racism. Moreover, engaging in discussions that facilitate deeper insights into structural processes that engender racial inequalities, is thwarted by the power of white discomfort, which potentially shifts the learning environment into a space where racially marginalized students' experiences would have to be defended or they are called upon to prove how racism is different from any other type of oppression or suffering. This is particularly problematic given that students must learn to thoughtfully navigate the contemporary highly racially charged sociopolitical climate and rhetoric that coexists with the widespread belief in a diverse and a colorblind society.

\section{Logic of Diversity in an Increasingly Multiracial Society}

As stated earlier, it is important to understand contemporary features of racism wherein words such as diversity and inclusion are commonplace and embraced by broader society. Yet, as Smith and Mayorga-Gallo (2017) maintain, diversity ideology is embedded within neoliberal logic. Meaning that neoliberalism is a "governing agenda that included the increased privatisation of government programs and institutions like public schools or even prisons," and it "also involves an intensifying rhetoric that is grounded in the belief that markets, in and of themselves, are better able than governments to produce, in particular, economic outcomes that are fair, sensible, and good for all" (Cohen 2010, as cited in Smith and Mayorga-Gallo 2017, 897). Smith and Mayorga-Gallo (2017) define diversity ideology as a way whites maintain dominance even in multiracial spaces. It is similar to colorblind racism but differs in that it centers an appreciation and lauding of racial differences. It essentially highlights race to "achieve" colorblindness.

Smith and Mayorga-Gallo's 2017 study analyses the responses of 43 face-to-face interviews with white Millennials in an attempt to understand how whites continue to maintain power, economic apartheid, in a society that is becoming increasingly multiracial. The authors found that educated white Millennials, in fact, adhere to and use diversity ideology to navigate contemporary racial issues. The study found that diversity ideology helped whites move between valuing diversity and maintaining a lack of support for policies that would bring those values to fruition. In such cases, "otherness," as it pertains to non-white people, became commodified. In this case, diversity was viewed or used as a good to be consumed by whites to fulfill an individual desire or to market themselves as more attractive in the marketplace (Smith and Mayorga-Gallo 2017). The authors found that diversity for most of their white respondents was defined as symbolic representation that may or may not have included racial diversity, with no thought of the ongoing structural impact of various individuals' life chances. 
Smith and Mayorga-Gallo (2017) findings provide insight into the gap between diversity ideology and having solid understanding of existing power relations and racial hierarchies. Within the context of diversity ideology, St. Clair and Kishimoto (2010) argue that diversity initiatives can prevent fruitful implementation of college and university course content covering race and ethnic groups/studies in ways that thwarts understanding the white supremacist system that continues to produce racial hierarchies. The integration of race into college settings in the 1960s and 1970s brought about specific challenges to teaching about race (St. Clair and Kishimoto 2010) and to decolonizing school curricula (Cooper 2012; Smith 2012). With the emergence of diversity and multiculturalism in the 1980s, these challenges became more arduous in response to the demand to accommodate multiculturalism in an increasingly privatized and corporatized society (Mohanty 2004; Smith and Mayorga-Gallo 2017; St. Clair and Kishimoto 2010). Ethnicity/race-related courses or topics runs the risk of being compartmentalized in college curricula and are often co-opted and transformed as diversity and multiculturalism requisites that in turn dodge challenging issues including White privilege, institutional racism, social position and oppression (Deckert 2014; Kitossa 2012; St. Clair and Kishimoto 2010).

\section{Colorblindness and the Possibility for Social Change}

An extensive scholarship exists that expounds upon the workings and the negative implications of colorblindness as well as the recent call to move beyond its early articulation (see, e.g., Alexander 2012; Burke 2017; Bonillia-Silva 2006; Burke 2017; Collins 2006, 2013; Robertson 2015; Smith and Mayorga-Gallo 2017; Vargas 2014). Colorblind discourse hides white privilege behind the mask of meritocracy which renders institutional arrangements that perpetuate racial inequality invisible (Alexander 2012; Bonillia-Silva 2006; Burke 2014/2017; Vargas 2014). Eduardo Bonilla-Silva's (2006), now, classic work examines how colorblind ideology preserves white supremacy. He argues that while not all whites adhere to white supremacy, a majority do in a casual, uncritical fashion, which works to sustain the prevailing racial order. For example, Vargas (2014), in his study of the relationship between racial contestation and colorblind adherence, found that contested whites, individuals who identify racially as white but are perceived by others as non-white, express similar or amplified notions of colorblindness as their non-contested white counterparts. His study suggests that because contested whites find themselves at the margins of whiteness they often seek to legitimate their group membership as white by adhering to colorblindness. Since race and racisms are believed to be inconsequential in a supposedly post-racial society, adherents to colorblindness believe the best way to get past racism is to simply stop talking about race. Those who embrace colorblindness believe that talking about race perpetuates the belief that there is a race problem (Bonilla-Silva 2006; Burke 2017; Collins 2013; Vargas 2014). Of course, we should believe there is a race 
problem. As evidenced by the gross racism and social inequalities in the United States, which clearly indicates that the country is not a post-racial paradise.

For example, Sarah Maddison (2011) examination of the challenges between black and white relations in Australia revealed that discussions of race/racism are avoided in efforts to circumvent or deny guilt. Yet, such attempts do not erase the existence of racism or guilt. Therefore, Maddison (2011) argues that considerable attention should be devoted to understanding collective guilt and its potential to facilitate meaningful social change (Maddison 2011). For example, investigations of the dimensions of white guilt revealed that it is important to distinguish healthy white guilt from unhealthy white guilt, stating that the former leads to change and transformation while the latter leads to paralysis and inaction (DiAngelo 2011; Maddison 2011; Spanierman et al. 2005). When the focus or concern is on how one feels (as a white person) about the issue of race and racism (inward focused), the guilt is deemed unhealthy thereby inhibiting progressive actions towards social justice. Even if one is motivated by white guilt to take a particular action, unhealthy guilt leads to white saviorism wherein white superiority stance/belief remains unquestioned and intact (Finnegan 2013). For example, Amy C. Finnegan (2013) examined young white-middle class North American female attraction to the Kony 2012 political movement, which sought the capture of the leader, Joseph Kony, of the Lord's Resistance Army in Eastern and Central Africa. In her article, The White Girl's Burden, she interviewed young white evangelical women participating in the Invisible Children organization. Her study found that many of the young girls/ women, ages 14-24, had very little to no knowledge of the history of the African countries affected and the social forces creating the harsh realities, especially the United States' role in constructing the structural violence in that part of the world. Participation in the movement was described as sexy and a mark of individuality. Most of the participants expressed that belonging to something bigger than themselves evoked feelings of specialness. Finnegan $(2013,33)$ called attention to the remoteness of the conflict as an important source of attraction.

\footnotetext{
The remoteness of the conflict facilitates an easy, noncontentious form of activism that does not threaten the students' futures. By inspiring them to think beyond themselves, to set bold goals, and to be creative in their efforts to raise awareness and funds for children in eastern and central Africa, the organization offers opportunities for young Americans to feel that their contributions are truly unique and noteworthy. Ultimately, however, Invisible Children also promotes policies that are highly controversial; its state-centric orientation seeks to eliminate the LRA through U.S.-supported military intervention carried out by the Ugandan army.
}

Finnegan's (2013) study found that the actions taken contributed very little to mitigating the structural violence in the affected areas in central Africa but, instead, perpetuated the exoticization of the other and reinforced a white superiority position. Actions (e.g., fundraising, rallies, and visits) were taken with very little examination of whiteness/privilege.

I found the enthusiasm to come to the aid of the exotic other is pervasive among many sociology students. However, students' enthusiasm tends to wane when asked 
to identify the social forces in their own communities, states, and countries that have contributed to unequal experiences of citizenship today. Thus, unhealthy guilt does not seek to understand whiteness and examine contemporary ways white supremacy is exercised and benefits white individuals. Whereas healthier responses to guilt use guilty feelings to understand the sources and outcomes of the injustices in a racist system (outward focused) (Maddison 2011). Actions are then directed to oppose racism and racist/discriminatory policies/practices rather than adopting an "apolitical" stance or becoming ambivalent. Maddison (2011) argues that the personal nature of guilt, when collective, can be a powerful political tool, specifically as a driver of transformative change, if guilt is recognized and processed in ways that are healthy.

\section{Epistemic Exploitation}

Like white guilt, epistemic exploitation is also physically and emotionally draining, but it lacks the comforts of privilege for which to retreat. Black feminist scholars across different genres have spoken for years about this type of exploitation as an extension of oppression (see, e.g., Cooper 2015; Dotson 2011, 2014; Morrison 1975). Characterized by unrecognized, uncompensated, emotionally taxing, coerced epistemic labor, epistemic exploitation maintains structures of oppression by making the needs and desires of dominant groups central to the interactions all people have in society (Berenstain 2016; Dotson 2014). Formal settings, such as the classroom, can be prime locations where emotional and cognitive labor is exploited. Instead of being an intellectual space used to tackle racism and equip students to reflect and become active participants in creating a just society, formal spaces can be disempowering for individuals from structurally disadvantaged groups. This occurs because individuals within these structurally disadvantaged groups are tacitly (or even explicitly) expected to be the ones who take on the burden of explaining how and why disadvantage has accrued, and the burden of arguing for changes that will ameliorate this burden both for currently existing persons and for future persons (Berenstain 2016). Meanwhile, those who benefit from the status quo are not expected to shoulder this burden.

\section{Conclusion}

This chapter argues that white guilt and fragility are almost always present, albeit in diverse forms depending on the country in question. It argues that colorblind and diversity ideologies are intricately linked to white fragility/guilt as some type of colorblind stance is likely a strategy deployed to minimize charges of racism. Burke (2017) argues for the need to more deeply examine the mechanisms of contemporary colorblind racism. Because racial dynamics evolve and shift over time and space, so too will the ideologies and discourses that surround them (Burke 2017). Enhancing 
our understanding of how white fragility and guilt influence discussions of race/ racism is paramount if we are to engage in fruitful discussion of racial justice.

From this basis, I argue that diversity ideology caters to white fragility and guilt in specific ways. The massive appeal to be a part of something that is supposedly inclusive and celebrates differences, but never interrogates whiteness and white supremacy, has worked to strengthen white supremacy, which undergirds unequal life chances and experiences of citizenship. Academic classrooms should be the space where critical thinking about race/racism occurs. If white fragility/guilt is not accounted for and neutralized, academic spaces cannot equip students with the correct knowledge to bring about racial justices. Moreover, even those spaces created to discuss and implement diversity needs becomes another space to placate white guilt and therefore reproduce the same outcomes in the absence of a so-called diversity program. Diversity, in this neo-liberal era, inadvertently caters to the demands of white comfort and individuals racialized as non-white are again called upon to justify their claims and explain what makes racial oppression different from other social ailings experienced by racially advantaged groups such as disability, sexuality, or social class. If change is to occur, white fragility and guilt must be recognized as a prevailing feature preventing critical discussions of racial injustice.

\section{References}

Alexander M (2012) The new jim Crow: Mass incarceration in the age of colorblindness, revised edn. New Press, New York

Baldwin J (1963) A talk to teacher. The Saturday Review, December 21

Bell JM, Hartmann D (2007) Diversity in everyday discourse: the cultural ambiguities and consequences of happy talk. Am Sociol Rev 72(6):895-914

Berenstain N (2016) Epistemic exploitation. Ergo 3(22):569-590

Boler M (1999) Feeling power: emotions and education. Routledge, New York, NY

Bonilla-Silva E (2006) Racism without racists: Color-blind racism and the persistence of racial inequality in the United States (2nd ed.). Oxford, England: Rowman \& Littlefield

Burke MA (2014) Colorblindness vs. race-consciousness - an american ambivalence. In: Hartmann D, Uggen C (eds) Color lines and racial angles. W.W. Norton, New York, pp 165-176

Burke MA (2017) Colorblind racism: identities, ideologies, and shifting subjectivities. Sociol Perspect 60(5):857-865

Collins PH (2006) From Black power to hip hop: racism, nationalism, and feminism. Temple University Press, Philadelphia

Collins PH (2013) On intellectual activism. Temple University Press, Philadelphia, PA

Cooper G (2008) Tawhaki and Māui: critical literacy in indigenous epistemologies. Crit Lit Theor Pract 2(1):37-42

Cooper G (2012) Kaupapa Māori research: epistemic wilderness as freedom? N Z J Educ Stud 47(2):64-73

Cooper B (2015) Black America's hidden tax: why this feminist of color is going on strike. Salon. Retrieved 10 Oct 2017 from https://www.salon.com/2015/02/25/black_americas_hidden_tax_ why_this_feminist_of_color_is_going_on_strike/

Davis A (1996) Gender, class, and multiculturalism: rethinking 'race' politics. In: Gordon AF, Newfield C (eds) Mapping multiculturalism. University of Minnesota, Minneapolis, pp 40-48 
Deckert A (2014) Neo-colonial criminology: quantifying the silence. Afr J Crim Justice Stud 8:39-60

DiAngelo R (2011) White fragility. Int J Crit Pedagog 3(3):54-70

Dotson K (2011) Tracking epistemic violence, tracking practices of silencing. Hypatia 26(2):236-257

Dotson K (2014) Conceptualizing epistemic oppression. Soc Epistemol 28(2):115-138

Finnegan AC (2013) The white girl's burden. Context 12(1):30-35

Gans E (2007) White guilt, past and future. Anthropoetics 12(2):1-8

Goodman DJ (2011) Promoting diversity and social justice: educating people from privileged groups. Routledge, New York

Iyer A, Leach CW, Crosby FJ (2003) White guilt and racial compensation: the benefits and limits of self-focus. Personal Soc Psychol Bull 29(1):117-129

Kirabo S (2015) Want to help end systemic racism? First step: drop the white guilt. Retrieved 31 Aug 2015 at http://thehumanist.com/commentary/want-to-help-end-systemic-rac ism-first-step-drop-the-white-guilt

Kitossa T (2012) Criminology and colonialism: counter colonial criminology and the Canadian context. J Pan Afr Stud 4:204-226

Ladner JA (1971) Tommorrow's tommrrow. Doubleday and Company, Garden City

Loewen JW (2007) Lies my teacher told me. Touchstone, New York

Lorde A (1995) Age, race, class, and sex: women redefining difference. In: Beverly Guy-Sheftall (ed) Words of Fire: An anthology of African-American feminist thought. The New Press, New York, pp 284-292

Luft R E (2009) Intersectionality and the risk of flattening difference: gender and race logics, and the strategic use of antiracist singularity. In: Berger M T, Guidroz K (eds) The Intersectional Approach: Transforming the Academy Through Race, Class, \& Gender The University of North Carolina Press, Chapel Hill, NC, pp. 100-117

Lydacker JA, Hubbard RR, Tully CB, Utsey SO, Mezzeo SE (2014) White public regard: associations among eating disorder symptomatology, guilt, and white guilt in young adult women. Eat Behav 15:76-82

Maddison S (2011) Beyond white guilt: the real challenge for black-white relations in Australia. Allen and Unwin, Australia

Mills C (1998) blackness visible: essays on philosophy and race. In: Ithaca. Cornell University Press, London

Mohanty CT (2004) Feminism without borders: decolonizing theory, practicing solidarity. Duke University Press, Durham

Morrison T (1975) A humanistic view. In: Public dialogue on the American Dream Them, Part 2. Panel conducted by the Portland State Black Studies Center, Neville.

Murphy-Erby Y, Hunt V, Zajicek AM, Norris AN, Hamilton L (2009) Incorporating intersectionality in social work research, education, policy, and practice. National Association of Social Workers Press, Washington, DC

Nadan Y, Stark M (2016) The pedagogy of discomfort: enhancing reflectivity on stereotypes and bias. Br J Soc Work 47(3):683-700

Norris AN (2017) Are we really colour-blind? The normalization of mass female incarceration. Race Justice 1-25. https://doi.org/10.1177/2153368717718028

Pitcher B (2011) Radical subjects after hegemony. Subjectivity 4(1):87-102

Reilly K (2016) How guns on campus could change what texas teaches. Time, February 26.

Robertson DL (2015) Invisibility in the color-blind era: examining legitimized racism against indigenous peoples. Am Indian Q 39:113-153

Smith L (2012) Decolonizing methodologies: research and indigenous peoples, 2nd edn. University of Otago Press, Dunedin

Smith C (2017) Why James Baldwin's 'A talk to teacher' Remains relevant 54 years later. Wbur. Retrieved 9 Oct 2017 from http://www.wbur.org/hereandnow/2017/10/03/jamesbaldwin-talk-to-teachers 
Smith CW, Mayorga-Gallo S (2017) The new principle-policy gap: how diversity ideology subverts diversity initiatives. Sociol Perspect 60(5):889-911

Spanierman LB, Todd NR, Anderson CJ (2005) Psychosocial costs of racism to whites: understanding patterns among university students. J Couns Psychol 56(2):239-252

St. Clair D, Kishimoto K (2010) Decolonizing teaching: a cross-curricular and collaborative model for teaching about race in the university. Multicult Educ 18(1):18-24

Swim JK, Miller DL (1999) White guilt: its antecedents and consequences for attitudes toward affirmative action. Personal Soc Psychol Bull 25(4):500-514

Todd NR, Abrams EM (2011) White dialectics: a new framework for theory, research, and practice with white students. Couns Psychol 39(3):353-395

Vargas N (2014) Off white: colour-blind ideology at the margins of whiteness. Ethn Racial Stud 37(13):2281-2302

Woodson CG (1933) Mis-education of the Negro. Khalif Khalifah, Drewryville

Yeung JG, Spanierman LB, Landrum-Brown J (2013) Being white in a multicultural society: critical whiteness pedagogy in a dialogue course. Journal of Diversity in Higher Education 6(1):17-32

Younge G (2015) White guilt won't fix America's race problem. Only justice and equality will. The Guardian, August 31

Zajicek AM (2002) Race discourses and antiracist practices in local women's movement. Gend Soc 16(2):151-170 